\title{
A Disease Register for ME/CFS: Report of a Pilot Study
}

\author{
Derek Pheby ${ }^{1 *}$, Eliana Lacerda ${ }^{2}$, Luis Nacul ${ }^{2}$, Maria de Lourdes Drachler ${ }^{3}$, Peter Campion ${ }^{4}$, Amanda Howe $^{3}$, \\ Fiona Poland ${ }^{3}$, Monica Curran ${ }^{3}$, Valerie Featherstone ${ }^{4}$, Shagufta Fayyaz ${ }^{2}$, Dikaios Sakellariou ${ }^{5}$ and \\ José Carlos de Carvalho Leite $^{3}$
}

\begin{abstract}
Background: The ME/CFS Disease Register is one of six subprojects within the National ME/CFS Observatory, a research programme funded by the Big Lottery Fund and sponsored by Action for ME. A pilot study in East Anglia, East Yorkshire, and London aimed to address the problem of identifying representative groups of subjects for research, in order to be able to draw conclusions applicable to the whole ME/CFS population.

While not aiming for comprehensive population coverage, this pilot register sought to recruit participants with ME/ CFS in an unbiased way from a large population base. Those recruited are constituting a cohort for long-term follow-up to shed light on prognosis, and a sampling frame for other studies.

Findings: Patients with unidentified chronic fatigue were identified in GP databases using a READ-code based algorithm, and conformity to certain case definitions for ME/CFS determined. 29 practices, covering a population aged 18 to 64 of 143,153, participated.

510 patients with unexplained chronic fatigue were identified. 265 of these conformed to one or more case definitions. 216 were invited to join the register; 160 agreed. 96.9\% of participants conformed to the CDC 1994 (Fukuda) definition; the Canadian definition defined more precisely a subset of these. The addition of an epidemiological case definition increased case ascertainment by approximately $4 \%$. A small-scale study in a specialist referral service in East Anglia was also undertaken.

There was little difference in pattern of conformity to case definitions, age or sex among disease register participants compared with subjects in a parallel epidemiological study who declined to participate.

One-year follow-up of 50 subjects showed little change in pain or fatigue scores. There were some changes in conformity to case definitions.

Conclusions: Objective evaluation indicated that the aim of recruiting participants with ME/CFS to a Disease Register had been fulfilled, and confirmed the feasibility of our approach to case identification, data processing, transmission, storage, and analysis. Future developments should include expansion of the ME/CFS Register and its linkage to a tissue sample bank and post mortem tissue archive, to facilitate support for further research studies.
\end{abstract}

\section{Background}

The myalgic encephalomyelitis/chronic fatigue syndrome (ME/CFS) Disease Register pilot feasibility study, in East Anglia, East Yorkshire, and London, is part of the National ME/CFS Observatory project, funded by the Big Lottery Fund and sponsored by the charity Action

\footnotetext{
* Correspondence: derekpheby@btinternet.com

'Buckinghamshire New University, Uxbridge Campus, 106, Oxford Road, Uxbridge, Middlesex, UB8 1NA, UK

Full list of author information is available at the end of the article
}

for ME. The programme is managed in close liaison with people with ME/CFS and carers.

The study objectives were to:-

- establish a disease register for ME/CFS.

- demonstrate that it can be managed in accordance with legal and ethical requirements.

- assess the effectiveness and comprehensiveness of case ascertainment methods in different communities.

- determine whether or not duplicate entries could be readily detected.

- assess the feasibility of regular follow-up.

\section{Biomed Central}


- confirm that the data transmission and processing methods were demonstrably secure.

- involve people with ME/CFS and carers in the management of the project.

Disease registers, including the American Veterans' Affairs Gulf War Registry [1,2] and twin registries, have been used to study ME/CFS. Swedish Twin Registry studies showed CFS to be associated with premorbid stress [3-5]. American twin registry studies [6,7] showed that the prevalence of fatiguing illness depended on case definition [8]. A disease-specific twin registry for chronic fatigue has now been established [9].

A 2002 review of disease registers in England [10] asserted that in chronic diseases "... an accurate wellmaintained register is a prerequisite to providing comprehensive and coordinated care" [11]. With governmental commitment to establish disease registers in mind [12], the authors identified approximately 250 disease registers recording all cases of a disease in a population, which they distinguished from clinical databases [10]. Our study did not aim at comprehensive population coverage, which would have been unrealistic as many doctors do not recognise the existence of ME/ CFS, nor diagnose it [13]. Rather, the study addresses a problem of ME/CFS research, where frequently findings of intervention studies in unrepresentative groups, e.g. excluding severely incapacitated patients, are extrapolated to the whole ME/CFS population. The NICE guidelines on ME/CFS [14] have been criticised on these grounds [15]. Similar problems arise in epidemiological studies [16].

The disease register sought to recruit participants in an unbiased way from a large population. They will be followed up long-term, since little is known about prognosis [17] The register will also constitute a sampling frame for other studies, including intervention studies, to generate results capable of being generalised to the whole ME/CFS population.

\section{Methods}

A descriptive epidemiological study of ME/CFS was carried out in three English regions. General practices in East Yorkshire and East Anglia were invited to participate by the local academic Primary Care Departments in the universities of Hull and East Anglia respectively, and in London by the relevant Primary Care Trust. Patients with unexplained chronic fatigue were identified in GPs' computerised databases by an algorithm identifying READ diagnostic terms indicating probable or possible ME/CFS, while excluding other fatiguing conditions. The primary diagnostic terms (indicating probable ME/CFS) were chronic fatigue syndrome, post viral asthenic syndrome, neurasthenia, fatigue syndrome, post infectious encephalitis, and fibromyalgia. Secondary diagnoses, indicating possible ME/CFS, were 'Tired all the time' (TATT), asthenia, tiredness, fatigue, and neurasthenia or nervous debility. The exclusions were Addison's disease, Cushing's syndrome, hypothyroidism, hyperthyroidism, diabetes mellitus, anaemia, iron deficiency or overload, cancer, rheumatological and autoimmune disorders (rheumatoid arthritis, lupus, polymyositis and polymyalgia rheumatic), AIDS, multiple sclerosis, parkinsonism, myasthenia gravis, B12 deficiency, active infections (tuberculosis, chronic hepatitis), alcohol or substance abuse, sleep apnoea, major psychiatric disorders including bipolar disorder, psychosis and anorexia/bulimia, and major organ failure.

GPs reviewed patients with primary diagnoses to exclude those with symptoms explicable by other diagnoses, or whose participation was contraindicated for personal or clinical reasons. Those with secondary diagnoses were also reviewed. Patients identified were invited to participate in the descriptive epidemiological study, and sent an information sheet and consent form, and symptom assessment instruments. Data was entered locally and transmitted using secure on-line communications to the London School of Hygiene and Tropical Medicine (LSHTM), where a web-based bespoke system was hosted on a UNIX web server using PHP and MySQL database. The system used an encrypted Secure Sockets Layer (SSL) to encrypt data interactions. Personal data was also encrypted. A computerised algorithm was applied to the symptom assessment data to identify subjects who fulfilled at least one of three case definitions, i.e.

(a) The CDC 1994 (Fukuda) definition [18], the most widely used case definition in ME/CFS research,

(b) The Canadian definition [19], recently promulgated and thought to define more precisely patients with unequivocal ME/CFS,

(c) An epidemiological case definition [20], intended to be a robust yet simplified and more inclusive definition of ME/CFS for epidemiological studies. This has two levels, 1 , identifying mild to moderate disease, and 2 , identifying more severely affected subjects, with a different symptom profile.

Subjects conforming to at least one case definition, unless they did not know or did not accept that they had ME/CFS, were contacted and invited to participate in the Disease Register. A subset of participant data, comprising and GP practice identifiers, contact details, personal characteristics (date of birth, gender, ethnicity), details of consent, and conformity to case definitions, was then held in the LSHTM system.

Participants completed other assessment instruments, including SF-36 [21] and visual analogue scales for pain and fatigue. After one year, a sample of fifty participants was followed up with a further questionnaire, to assess effectiveness of follow-up procedures. 
A small-scale study of cases attending a specialist referral service in East Anglia (i.e. covering the area of some participating practices) was also undertaken, to increase the basis of recruitment, and to examine the effectiveness of duplicate entry identification.

For analysis, a severe case is one with (i) tiredness/fatigue most days, (ii) unable to do activities because of tiredness/fatigue, (iii) activities reduced more than 50\% since falling ill, (iv) fatigue debilitating and affecting mental and physical functioning, and (v) pain score eight out of ten, and/or fatigue score eighty out of a hundred, or more.

The study was approved by the London Multi-Centre Research Ethics Committee, and the Ethics Committee of LSHTM.

\section{Results}

The study reviewed case ascertainment methods, procedures for handling duplicate registrations, validity and appropriateness of primary care-based data collection methods in ethnically and socially diverse populations, follow-up arrangements, and effectiveness and legal and ethical compliance of data management, including data access, data security, and monitoring data quality, i.e. completeness, comprehensiveness, accuracy and timeliness. We established arrangements for accountability, reporting and publicity and a clinical network to support the work of the register. These are considered in the 'Discussion' section.

The 29 participating practices covered a population aged 18 to 64 inclusive of 143,153 . Five practices were in East Anglia and five in London. There were nineteen, on average smaller, practices in East Yorkshire. Among this population, 510 patients with unexplained chronic fatigue were identified, and 265 conformed to one or more case definitions. 216 were invited to participate in the register, and 160 agreed.

\section{Conformity to Case Definitions}

Figure 1 illustrates distribution by case definition. Most cases (96.9\%) fulfilled the CDC 1994 (Fukuda) definition, while the Canadian definition defined more precisely a subset of these. Use of the epidemiological case definition increased overall ascertainment by nearly $4 \%$.

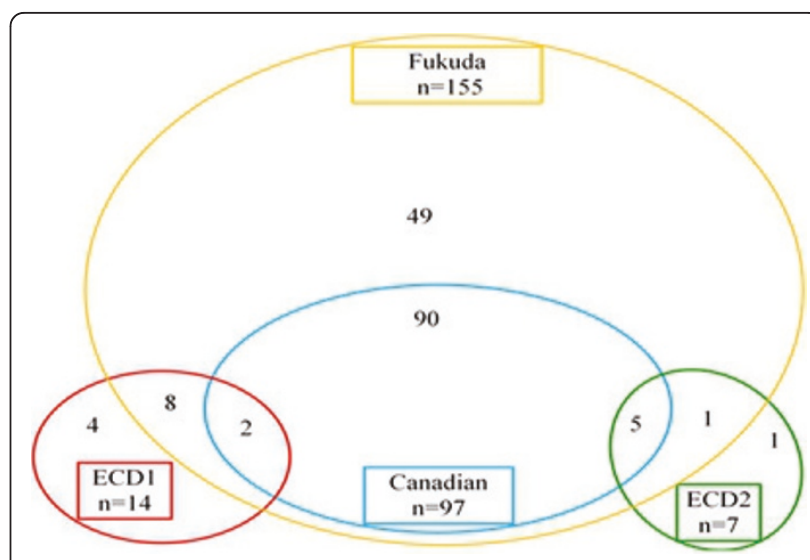

Figure 1 The inter-relationship of diagnostic definitions used in the ME/CFS Disease Register Pilot Study.

There was little difference in conformity to case definitions between disease register participants, nonparticipants or epidemiological study subjects overall (Table 1).

Of five cases conforming to the epidemiological case definition but not to the CDC (1994) definition, three manifested only three of the 1994 CDC definition's minor criteria, not the required four, one had other illnesses which were exclusions from the CDC 1994 definition, while the fifth had illness of indefinite onset.

Cases meeting the Canadian definition were compared with CDC (1994) positive cases that did not (Table 2). There were no significant differences in age or sex distribution. None of the participants who reported fatigue less frequently than every day, or who did not regard their fatigue as debilitating, conformed to the Canadian definition. Those conforming to the Canadian definition tended to report a greater impact of fatigue on activities, a greater reduction in activity levels since falling ill, higher pain levels, and higher fatigue levels on recruitment.

Table 3 compares age group and sex distribution, and table 4 levels of severity, in Register participants and non-participants.

$80.0 \%$ of males approached agreed to participate, and $72.4 \%$ of females. Subjects from East Anglia were most

Table 1 Conformity of Epidemiological Study and Disease Register Participants to Case Definitions

\begin{tabular}{|c|c|c|c|c|c|c|}
\hline \multirow{3}{*}{$\begin{array}{l}\text { Case } \\
\text { Definition }\end{array}$} & \multicolumn{4}{|c|}{ Epidemiological Study } & \multicolumn{2}{|r|}{ Disease Register } \\
\hline & \multicolumn{2}{|r|}{ All subjects } & \multicolumn{2}{|c|}{ Subjects not in disease register } & \multirow[b]{2}{*}{$\begin{array}{l}\text { No. } \\
\text { cases }\end{array}$} & \multirow[b]{2}{*}{$\begin{array}{c}\% \text { total } \\
\text { (95\% confidence interval) }\end{array}$} \\
\hline & $\begin{array}{c}\text { No. } \\
\text { cases }\end{array}$ & $\begin{array}{c}\% \text { total } \\
\text { (95\% confidence interval) }\end{array}$ & $\begin{array}{c}\text { No. } \\
\text { cases }\end{array}$ & $\begin{array}{c}\% \text { total } \\
\text { (95\% confidence interval) }\end{array}$ & & \\
\hline Fukuda & 282 & $96.9(94.8-99.0)$ & 127 & $96.9(93.9-100.0)$ & 155 & $96.9(94.1-99.7$ \\
\hline Canadian & 154 & $52.9(44.9-61.0)$ & 57 & $43.5(30.4-56.6)$ & 97 & $60.6(50.7-70.5)$ \\
\hline$\overline{\text { TOTAL }}$ & 291 & 100.0 & 131 & 100.0 & 160 & 100.0 \\
\hline
\end{tabular}


Table 2 Fukuda definition-positive subjects conforming or not conforming to the Canadian case definition

\begin{tabular}{|c|c|c|c|}
\hline & $\begin{array}{c}\text { Cases } \\
\text { fulfilling } \\
\text { case } \\
\text { definition } \\
(n=122)\end{array}$ & $\begin{array}{l}\text { Cases not } \\
\text { fulfilling } \\
\text { case } \\
\text { definition } \\
(\mathrm{n}=87)\end{array}$ & \multirow[t]{2}{*}{$\begin{array}{l}95 \% \text { confidence interval } \\
\text { (difference in percentages) }\end{array}$} \\
\hline & No. $\begin{array}{c}\% \\
\text { total }\end{array}$ & No. $\begin{array}{c}\% \\
\text { total }\end{array}$ & \\
\hline Age Group: $<25$ & 0.8 & 4.6 & $-8.6-1.0$ \\
\hline $25-34$ & $15 \quad 12.3$ & 6.9 & $-2.7-1.5$ \\
\hline $35-44$ & $32 \quad 26.2$ & $19 \quad 21.8$ & $-7.5-1.3$ \\
\hline $45-54$ & $43 \quad 35.2$ & $28 \quad 32.2$ & $-10.2-1.3$ \\
\hline $55-64$ & $27 \quad 22.1$ & $30 \quad 34.5$ & $-25.0-0.3$ \\
\hline $65+$ & 3.3 & 1.1 & $-1.8-6.1$ \\
\hline Sex: Male & $25 \quad 20.5$ & $15 \quad 17.2$ & $-7.7-14.2$ \\
\hline Female & $97 \quad 79.5$ & $72 \quad 82.8$ & $-14.2-7.7$ \\
\hline \multicolumn{4}{|l|}{ How often do you have tiredness/fatigue? } \\
\hline Occasionally & 0.0 & 1.1 & $-3.4-1.1$ \\
\hline$<3$ times/week & 0.0 & 8.0 & $-13.9--2.2$ \\
\hline Every day or nearly every day & $122 \quad 100.0$ & 7990.8 & $3.0-15.4$ \\
\hline \multicolumn{4}{|c|}{$\begin{array}{l}\text { Were your activities (personal, social, professional, at home) affected by the } \\
\text { symptoms of tiredness/fatigue? }\end{array}$} \\
\hline Not at all & 0.0 & 0.0 & $0.0-0.0$ \\
\hline A little & 0.0 & 0.0 & $0.0-0.0$ \\
\hline Needed to reduce & 9.0 & $36 \quad 41.4$ & $-44.1--20.6$ \\
\hline Can no longer do & 11191.0 & $51 \quad 58.6$ & $20.6-44.1$ \\
\hline \multicolumn{4}{|c|}{$\begin{array}{l}\text { Would you say that your activities were reduced to }<50 \% \text { than before you fell } \\
\text { ill? }\end{array}$} \\
\hline Yes, by $>50 \%$ & 11695.1 & $70 \quad 80.5$ & $5.3-24.0$ \\
\hline No, by $50 \%$ or less & 3.3 & $10 \quad 11.5$ & $-15.8--0.7$ \\
\hline Don't know & 1.6 & 6.9 & $-11.2-0.6$ \\
\hline \multicolumn{4}{|c|}{$\begin{array}{l}\text { Would you say that your fatigue is debilitating and affects your mental and } \\
\text { physical functioning? }\end{array}$} \\
\hline Yes & 122100.0 & 7990.8 & $3.0-15.4$ \\
\hline No & 0.0 & 4.6 & $-9.1--0.1$ \\
\hline Don't know & 0.0 & 3.4 & $-7.4-0.5$ \\
\hline \multicolumn{4}{|c|}{ Pain level (where $0=$ no pain, and $10=$ pain as bad as possible) } \\
\hline Mean & 6.0 & 4.6 & \\
\hline 95\% confidence interval & $5.6-6.4$ & $2.5-3.1$ & \\
\hline Standard deviation & 2.4 & 2.8 & \\
\hline Median & 6 & 5 & \\
\hline Interquartile range & $5-8$ & $2-7$ & \\
\hline No. reporting no pain & 2 & 9 & \\
\hline No. reporting maximum pain & 5 & 3 & \\
\hline \multicolumn{4}{|c|}{$\begin{array}{l}\text { Fatigue level on recruitment (where } 0=\text { no problem, and } 100=\text { the most } \\
\text { severe health impediment) }\end{array}$} \\
\hline Mean & 65.7 & 54.3 & \\
\hline 95\% confidence interval & $61.0-70.4$ & $50.0-58.6$ & \\
\hline Standard deviation & 26.1 & 21.0 & \\
\hline Median & 70 & 50 & \\
\hline Interquartile range & $50-80$ & $50-70$ & \\
\hline No. reporting no fatigue & 2 & 2 & \\
\hline No. reporting max. possible fatigue & 15 & 1 & \\
\hline
\end{tabular}


Table 3 Age and Sex Distribution among Disease Register Invitees, Participants, and Those Declining Invitation

\begin{tabular}{|c|c|c|c|c|c|c|}
\hline & \multicolumn{2}{|r|}{ All Invitees } & \multicolumn{2}{|c|}{ Not accepting Invitation } & \multicolumn{2}{|c|}{ Disease Register Participants } \\
\hline & $\begin{array}{l}\text { No. } \\
\text { cases }\end{array}$ & $\begin{array}{c}\% \text { total } \\
\text { (95\% confidence interval) }\end{array}$ & $\begin{array}{l}\text { No. } \\
\text { cases }\end{array}$ & $\begin{array}{c}\% \text { total } \\
\text { (95\% confidence interval) }\end{array}$ & $\begin{array}{l}\text { No. } \\
\text { cases }\end{array}$ & $\begin{array}{c}\% \text { total } \\
\text { (95\% confidence interval) }\end{array}$ \\
\hline \multicolumn{7}{|l|}{$\overline{S e x}$} \\
\hline Male & 42 & $19.4(7.2-31.7)$ & 8 & $14.3(0.0-39.0)$ & 34 & $21.3(7.2-35.3)$ \\
\hline Female & 174 & $80.6(74.6-86.6)$ & 48 & $85.7(75.6-95.8)$ & 126 & $78.8(71.5-86.0)$ \\
\hline \multicolumn{7}{|l|}{ Age group } \\
\hline$<25$ & 26 & $12.3(0.0-24.8)$ & 6 & $10.7(0.0-36.0)$ & 20 & $12.5(0.0-27.3)$ \\
\hline $25-44$ & 73 & $33.8(22.7-44.9)$ & 23 & $41.1(20.6-61.6)$ & 50 & $31.3(18.1-44.4)$ \\
\hline $45-64$ & 132 & $61.1(52.6-69.6)$ & 32 & $57.1(39.6-74.6)$ & 100 & $62.5(52.8-72.2)$ \\
\hline $65+$ & 6 & $2.8(0.0-16.2)$ & 1 & $1.8(0.0-29.3)$ & 5 & $3.1(0.0-18.7)$ \\
\hline \multicolumn{7}{|l|}{ Ethnicity } \\
\hline White British & 157 & $72.6(65.6-79.8)$ & 12 & $21.4(0.0-45.1)$ & 145 & $90.6(85.8-95.5)$ \\
\hline Other & 12 & $5.6(0.0-18.8)$ & 1 & $1.8(0.0-28.3)$ & 11 & $6.9(0.0-22.1)$ \\
\hline Not stated & 47 & $21.8(9.7-33.8)$ & 43 & $76.8(63.9-89.7)$ & 4 & $2.5(0.0-18.1)$ \\
\hline \multicolumn{7}{|l|}{ Region } \\
\hline London & 29 & $13.4(0.8-26.1)$ & 16 & $28.6(6.0-51.2)$ & 13 & $8.1(0.0-23.3)$ \\
\hline East Anglia & 81 & $37.5(26.7-48.3)$ & 15 & $26.8(3.9-49.7)$ & 66 & $41.3(29.1-53.4)$ \\
\hline $\begin{array}{l}\text { Yorks./ } \\
\text { Humberside }\end{array}$ & 105 & $48.6(38.9-58.4)$ & 25 & $44.6(24.8-64.5)$ & 80 & $50.0(38.8-61.2)$ \\
\hline Not stated & 1 & $0.4(0.0-14.9)$ & - & 0.0 & 1 & $0.6(0.0-16.4)$ \\
\hline$\overline{\text { TOTAL }}$ & 216 & 100.0 & 56 & 100.0 & 160 & 100.0 \\
\hline
\end{tabular}

likely to agree, and those from London least likely. Those not participating tended to report more severe symptoms than register participants, but this was not statistically significant.

Duration of illness prior to recruitment varied from 18 months to 27 years, with a mean of 127.3 months (standard deviation $=84.1$ months), and a median of 108 months. There was no difference between males (mean duration prior to recruitment $=128.1$ months) and females (mean duration prior to recruitment = 127.1 months) in this respect. The results regarding duration of illness prior to recruitment are summarised in table 5 .

\section{Follow-Up Results}

Pain and fatigue levels were recorded in fifty disease register subjects followed up after one year. Pain was assessed on a scale of 0 to 10 , where 0 indicated no pain and 10 maximum pain. Fatigue scores ranged from 0 to 100 , where 0 indicated no fatigue with exercise and 100 indicated maximum fatigue, bedridden, and unable to self-care. There was little change in either. The mean pain score on recruitment was 4.9, (median 5.0, interquartile range $2.0-7.0 ; \mathrm{n}=50$ ), and after one year the mean was 5.0 (median 5.7, interquartile range 2.6-7.0; $\mathrm{n}$ $=49, \mathrm{p}$ (paired $\mathrm{t}$-test $)=0.66)$. The mean fatigue score on recruitment was 61.6 (median 60 , interquartile range
50-70; $\mathrm{n}=49$ ), and after one year was 59.6 (median and interquartile range unchanged; $\mathrm{n}=46$ ).

Conformity to case definitions was assessed on follow up. Numbers of subjects conforming to CDC (1994) and Canadian definitions were reduced compared with recruitment, though conformity to case definitions was unchanged for 38 respondents (76\%). At recruitment, 49 subjects conformed to the CDC (1994) definition, but only 44 on follow up. 31 subjects conformed to the Canadian definition on recruitment; four no longer conformed at follow-up, but three additional subjects did.

\section{Discussion}

\section{Objective-Based Evaluation}

The case ascertainment methods worked effectively, in different communities, while the secondary care study showed duplicate entries could be readily detected. Regular follow-up is feasible, although a larger scale study is needed to assess drop-out rates. A disease register for ME/CFS can be established and managed in compliance with legal and ethical requirements. Our data transmission and processing methods are demonstrably secure. Researchers have used the register to identify participants for other studies, e.g. of gene expression. Little data is missing, but case ascertainment is not comprehensive; this was not achievable in 
Table 4 Severity distribution among disease register participants and non-participants

\begin{tabular}{|c|c|c|c|c|c|}
\hline & \multicolumn{2}{|c|}{$\begin{array}{l}\text { Participants } \\
(\mathrm{n}=158)\end{array}$} & \multicolumn{2}{|c|}{$\begin{array}{c}\text { Non- } \\
\text { Participants } \\
(\mathrm{n}=58)\end{array}$} & \multirow[t]{2}{*}{$\begin{array}{l}95 \% \text { confidence interval } \\
\text { (difference in percentages) }\end{array}$} \\
\hline & No. & $\%$ total & No. & $\%$ total & \\
\hline \multicolumn{6}{|l|}{ How often do you have tiredness/fatigue? } \\
\hline Occasionally & 1 & 0.6 & 0 & 0.0 & $-0.6-1.9$ \\
\hline$<3$ times/week & 6 & 3.8 & 2 & 3.4 & $-5.3-6.0$ \\
\hline Every day or nearly every day & 151 & 95.6 & 56 & 96.6 & $-6.8-4.8$ \\
\hline \multicolumn{6}{|c|}{$\begin{array}{l}\text { Were your activities (personal, social, professional, at home) affected by the } \\
\text { symptoms of tiredness/fatigue? }\end{array}$} \\
\hline Not at all & 0 & 0.0 & 0 & 0.0 & $0.0-0.0$ \\
\hline A little & 1 & 0.6 & 0 & 0.0 & $-0.6-1.9$ \\
\hline Needed to reduce & 35 & 22.2 & 13 & 22.4 & $-13.1-12.5$ \\
\hline Can no longer do & 122 & 77.2 & 45 & 77.6 & $-13.2-12.5$ \\
\hline \multicolumn{6}{|c|}{$\begin{array}{l}\text { Would you say that your activities were reduced to }<50 \% \text { than before you } \\
\text { fell ill? }\end{array}$} \\
\hline Yes, by > 50\% & 144 & 91.1 & 48 & 82.8 & $-2.5-19.3$ \\
\hline No, by $50 \%$ or less or not at all & 11 & 7.0 & 5 & 8.6 & $-10.1-6.8$ \\
\hline Don't know & 3 & 1.9 & 5 & 8.6 & $-14.4-1.0$ \\
\hline \multicolumn{6}{|c|}{$\begin{array}{l}\text { Would you say that your fatigue is debilitating and affects your mental and } \\
\text { physical functioning? }\end{array}$} \\
\hline Yes & 153 & 96.9 & 55 & 94.8 & $-4.4-8.5$ \\
\hline No & 3 & 1.9 & 1 & 1.7 & $-3.9-4.2$ \\
\hline Don't know & 2 & 1.3 & 1 & 1.7 & $-4.3-3.4$ \\
\hline \multicolumn{6}{|c|}{ Pain level (where $0=$ no pain, and $10=$ pain as bad as possible) } \\
\hline Mean & & 5.3 & & 5.6 & \\
\hline 95\% confidence interval Standard deviation & & $9-5.7$ & & $.5-6.7$ & \\
\hline \multirow[t]{2}{*}{ Median } & & 2.5 & & 2.1 & \\
\hline & & 6 & & 6 & \\
\hline \multicolumn{6}{|c|}{$\begin{array}{l}\text { Fatigue level on recruitment (where } 0=\text { no problem, and } 100=\text { the most } \\
\text { severe health impediment) }\end{array}$} \\
\hline Mean & & 66.0 & & 66.8 & \\
\hline 95\% confidence interval & 63. & $0-69.0$ & & $6-78.0$ & \\
\hline Standard deviation & & 18.3 & & 38.0 & \\
\hline Median & & $0<70$ & & $0<70$ & \\
\hline
\end{tabular}

the particular circumstances of ME/CFS. We established effective project management, including participation by people with ME/CFS and carers in the Project Steering Group.

Table 5 Duration of illness prior to recruitment

\begin{tabular}{lcccccc}
\hline $\begin{array}{l}\text { Duration } \\
\text { (years) }\end{array}$ & Males & \multicolumn{3}{c}{ Females } & & All Participants \\
\hline $\begin{array}{c}\text { No. } \\
\text { cases }\end{array}$ & $\begin{array}{c}\% \\
\text { total }\end{array}$ & $\begin{array}{c}\text { No. } \\
\text { cases }\end{array}$ & $\begin{array}{c}\% \\
\text { total }\end{array}$ & $\begin{array}{c}\text { No. } \\
\text { cases }\end{array}$ & $\begin{array}{c}\% \\
\text { total }\end{array}$ \\
\hline$<2$ & - & 0.0 & 1 & 1.3 & 1 & 1.0 \\
\hline $2<5$ & 2 & 8.7 & 18 & 22.8 & 20 & 19.6 \\
\hline $5<10$ & 10 & 43.5 & 23 & 29.1 & 33 & 32.3 \\
\hline $10<20$ & 9 & 39.1 & 25 & 31.6 & 34 & 33.3 \\
\hline $20+$ & 2 & 8.7 & 12 & 15.2 & 14 & 13.7 \\
\hline TOTAL & 23 & 100.0 & 79 & 100.0 & 102 & 100.0 \\
\hline
\end{tabular}

\section{Interpretation of Statistical Findings}

The results confirm that the Canadian definition [19] defines a subset of cases conforming to CDC(1994) [18]. Use of both definitions enabled us to take advantage of the sensitivity of the former and specificity of the latter.

We attempted to validate the epidemiological case definition [20]. Use of this as an adjunct to the CDC 1994 definition does mitigate under-ascertainment, but it is less inclusive than hoped. It includes some cases excluded by the CDC 1994 definition, but excludes many cases who do meet its requirements.

Disease register participants appear similar to descriptive epidemiological study cases in proportions conforming to various case definitions. Register participants are rather older on average than descriptive epidemiological study subjects, with a rather higher proportion of males. More than three-quarters of disease register participants 
were female. The modal age (nearly two-thirds of respondents), was 45-64, whereas previous research has suggested a modal age of 25-44 [22]. This may indicate a cohort effect.

Conformity to case definitions varied through time, suggesting that period prevalence rather than point prevalence may be appropriate in descriptive epidemiological studies. Use of formal definitions to identify cases of a syndrome is unsatisfactory, because boundaries are arbitrary and overlap with other syndromes [23], and different case definitions produce different findings in ME/CFS [24,25]. Until phenotypes are defined in terms of underlying pathology, this is unavoidable. However, this does not impede the register's purpose, to undertake long-term follow-up, and create a sampling frame for further studies.

\section{What this study adds}

This is the first systematic attempt to develop a population-based disease register specific to ME/CFS. Participation was voluntary, and we depended on GPs for recruitment of subjects. Many GPs remain reluctant to diagnose ME/CFS [13]. Furthermore, reliance on normative case definitions to determine eligibility for inclusion may result in under-ascertainment, as conformity varies over time.

The study confirmed the feasibility of our methods of case identification, data processing, transmission, storage and analysis, and demonstrated the potential of GP electronic records for identifying patients suitable for registration. Our study met Newton and Garner's requirements [10] of robust and appropriate case definitions, unbiased case ascertainment, and procedures for identifying duplicates and for follow-up.

\section{Future Developments}

For the future, we propose to continue to recruit to the register and to develop linked infrastructure facilities, including a tissue sample bank, to which register participants will be invited to contribute blood samples, e.g. to facilitate nested case-control studies of particular outcomes, with access to stored biological material and detailed follow-up data. A post mortem tissue archive is also proposed, and disease register participants will be invited to make advance declarations of willingness to contribute tissues after death.

Other complementary initiatives include the National Outcomes Database, an important infrastructure facility which collates patient data from NHS ME/CFS Collaborative clinical services[26]. This, though larger, differs significantly from the disease register. It is based on secondary care referrals, lacks a population base, and uses the broader case definition advocated by NICE [27].
Extending the use of the disease register as a sampling frame will require capacity to flag records indicating involvement in particular studies, to define additional data fields, and to link records to records in other databases. For outcomes assessment, a disease-specific patient-reported outcome measure (PROM) is needed, but meanwhile the London Handicap Scale [28], a sixitem validated instrument which facilitates inter-group comparisons, may be useful [29].

Extending the register to national coverage will require a major system upgrade, possibly involving a multiple tier architecture, including an application server to facilitate remote access for data collection and interrogation, a backend database server, and an offline data store to warehouse captured data. It also requires a web services API (Application Programming Interface) using XML, enabling authorised users to perform validated data submission as well as certain analyses of aggregated data from remote locations, to minimise data input errors and increase usability.

\section{Conclusions}

ME/CFS is a complex condition. This Disease Register pilot study has validated the methods used to set it up and has provided the basis for a range of initiatives to develop the evidence base needed to understand causes, clinical interventions and access to social support needed to address this challenging disease.

\section{List of Abbreviations}

ME/CFS: Myalgic encephalomyelitis/chronic fatigue syndrome; GP: General practitioner; CDC: Centers for Disease Control; SF-36: Short Form 36; LSHTM: London School of Hygiene and Tropical Medicine; NICE: National Institute for Health and Clinical Excellence; PROM: Patient Reported Outcome Measure; API: Application Programming Interface; XML: Extensible Markup Language;

\section{Acknowledgements}

We acknowledge with thanks the Big Lottery Fund, which provided financial support for this project. We also thank Action for ME, which sponsored the project, all the general practices who participated, Dr. Nagpal, of the Great Yarmouth ME/CFS clinical service, all the people with ME/CFS who consented to be part of the disease register and the participating carers, and also those who participated in the National ME/CFS Observatory Steering and Reference Groups.

\section{Author details}

'Buckinghamshire New University, Uxbridge Campus, 106, Oxford Road, Uxbridge, Middlesex, UB8 1NA, UK. '2London School of Hygiene and Tropical Medicine, Keppel Street, London, WC1E 7HT, UK. ${ }^{3}$ University of East Anglia, Norwich, NR4 7TJ, UK. ${ }^{4}$ University of Hull, Daisy Building (2nd. Floor) Castle Hill Hospital, Castle Road, Hull, HU16 5JQ, UK. ${ }^{5}$ School of Healthcare Studies, Cardiff University, Ty Dewi Sant, Heath Park Campus, Cardiff, CF14 4XN, UK.

\section{Authors' contributions}

DP was overall Project Coordinator for the National ME/CFS Observatory project, and Project Lead for the Disease Register sub-project. EL was Research Manager for the Disease Register, with responsibility for overall management of the sub-project. EL and LN were responsible for the development of the database and the associated algorithms. EL, LN, MD, PC, $A H, F P, J L, M C$, and VF were involved in design of the project, liaison with general practices, data collection, preparation, storage and transmission. SF 
and DS were research administrators at LSHTM, and responsible for day-today administration of the project. All authors were involved in the preparation of this report, and read and approved the final manuscript.

\section{Competing interests}

The authors declare that they have no competing interests.

Received: 3 November 2010 Accepted: 9 May 2011

Published: 9 May 2011

\section{References}

1. Fiedler N, Kipen H, Natelson B, Ottenweller J: Chemical sensitivities and the Gulf War: Department of Veterans' Affairs Research Center in basic and clinical science studies of environmental hazards. Regulatory Toxicology and Pharmacology 1996, 24(1pt2):S129-138.

2. Kipen HM, Hallman W, Kang H, Fiedler N, Natelson B: Presence of chronic fatigue and chemical sensitivities in Gulf Registry veterans. Archives of Environmental Health 1999, 54(5):313-318.

3. Pederson NL, Lichtenstein P, Svedberg P: The Swedish Twin Registry in the third millennium. Twin Research 2002, 5(5):427-432.

4. Sullivan PF, Pederson NL, Jacks A, Evengard B: Chronic Fatigue in a population sample: definitions and heterogeneity. Psychological Medicine 2005, 35(9):1337-1348.

5. Kato K, Sullivan PF, Evengard B, Pederson NL: Premorbid predictors of chronic fatigue. Archives of General Psychiatry 2006, 63(11):1267-1272.

6. Anderson LS, Beverley WT, Corey LA, Murrell L: The Mid-Atlantic Twin Registry. Twin Research 2002, 5(5):449-455.

7. Schur E, Afari L, Goldberg J, Buchwald D, Sullivan PF: Twin analyses of fatigue. Twin Research and Human Genetics 2007, 10(5):729-733.

8. Furberg H, Olarto M, Afari N, Goldberg J, Buchwald D: The presence of self-reported chronic fatigue in a US twin registry. Journal of Psychosomatic Research 2005, 59(5):283-290.

9. Buchwald D, Herrell R, Ashton S, Belcourt M, Schmaling K, Goldberg J: The Chronic Fatigue Twin Registry: method of construction, composition and zygosity assignment. Twin Research 1999, 2(3):203-211.

10. Newton J, Garner S: Disease Registers in England Oxford: Institute of Health Sciences; 2002

11. Cheales N, Howitt A: Personal experience with a district diabetic register located in general practice. In Chronic Disease Management Registers: Proceedings of a Workshop: 1996; London. Edited by: Dawson A, Ferrero M. HMSO; 1996:92-98.

12. Department of Health: Saving Lives: Our Healthier Nation London, HMSO; 1999, para. 11.33.

13. Bowen J, Pheby D, Charlett A, McNulty : Chronic Fatigue Syndrome: a survey of GPs' attitudes and knowledge. Family Practice 2005, 22(4):389-393.

14. Turnbull N, Shaw EJ, Baker R, Dunsdon S, Costin N, Britton G, Kuntze S, Norman R: Chronic Fatigue Syndrome/Myalgic Encephalomyelitis (or Encephalopathy): diagnosis and management of Chronic Fatigue Syndrome/Myalgic Encephalomyelitis (or Encephalopathy) in adults and children [The NICE Guideline on CFS/ME]. London, Royal College of General Practitioners; 2007.

15. National Institute for Health and Clinical Excellence: Chronic Fatigue Syndrome/Myalgic Encephalomyelitis Consultation Table (29 September - 24 November 2006). Comments on the NICE version by the National ME/CFS Observatory London: NICE; 2007, 241-280.

16. Pheby D, Saffron L: Risk factors for severe ME/CFS. Biology and Medicine 2009, 1(4):50-74

17. CFS/ME Working Group: Report - Annex 2, Prognosis of CFS/ME London: Department of Health; 2002.

18. Fukuda K, Strauss SE, Hickie I, Sharpe MC, Dobbins JG, Komaroff A, the International Chronic Fatigue Syndrome Study Group: The Chronic Fatigue Syndrome: a comprehensive approach to its definition and study. Ann Intern Med 1994, 121(12):953-959.

19. Carruthers BM, Jain AK, De Meirleir KL, Peterson DL, Klimas NG, Lerner AM, Bested AC, Flor-Henry P, Joshi P, Powles ACP, Sherkey JA, van de Sande Ml: Myalgic Encephalomyelitis/Chronic Fatigue Syndrome:Clinical Working Case Definition, Diagnostic and Treatment Guidelines - A Consensus Document. Journal of Chronic Fatigue Syndrome 2003, 11(1):7-115.
20. Osoba T, Pheby D, Gray S, Nacul L: The Development of an Epidemiological Definition for Myalgic Encephalomyelitis/Chronic Fatigue Syndrome. Journal of Chronic Fatigue Syndrome 2007, 14(4):61-84.

21. Ware JE, Sherbourne CD: The MOS 36-Item Short-Form Health Survey (SF36): I. conceptual framework and item selection. Medical Care 1992, 30(6):473-83.

22. CFS/ME Working Group: Report - Annex 1, Epidemiology of CFS/ME London: Department of Health; 2002.

23. Levine PH: Epidemiological aspects of CFS/ME. In The clinical and scientific basis of myalgic encephalomyelitis/chronic fatigue syndrome. Edited by: Hyde BM, Goldstein J, Levine P. Ottawa: Nightingale Research Foundation; 1992:196-205.

24. Levine PH: Epidemiologic advances in chronic fatigue syndrome. J Psychiatr Res 1997, 31:7-18.

25. Gunn WJ, Connell DB, Randall B: Epidemiology of chronic fatigue syndrome: the Centers for Disease Control study. Ciba Foundation Symposium no. 173 - Chronic fatigue syndrome Chichester: Wiley; 1993, 83-93.

26. Centre for Child and Adolescent Health: Annual Report: 2008 - 2009 Bristol; 2009, 16.

27. National Institute for Health and Clinical Excellence: NICE Clinical Guideline 53 - Chronic fatigue syndrome/myalgic encephalomyelitis (or encephalopathy): diagnosis and management of CFS/ME in adults and children London; 2007, paragraph 1.2.1.2..

28. Harwood RH, Rogers A, Dickinson E, Ebrahim S: Measuring handicap: The London Handicap Scale, a new outcome measure for chronic disease. Quality in Health Care 1994, 3:11-16.

29. Jenkinson C, Mant J, Carter J, Wade D, Winner S: The London handicap scale: a re-evaluation of its validity using standard scoring and simple summation. J Neurol Neurosurg Psychiatry 2000, 68:365-367.

doi:10.1186/1756-0500-4-139

Cite this article as: Pheby et al:: A Disease Register for ME/CFS: Report of a Pilot Study. BMC Research Notes 2011 4:139.

\section{Submit your next manuscript to BioMed Central and take full advantage of:}

- Convenient online submission

- Thorough peer review

- No space constraints or color figure charges

- Immediate publication on acceptance

- Inclusion in PubMed, CAS, Scopus and Google Scholar

- Research which is freely available for redistribution

Submit your manuscript at www.biomedcentral.com/submit
Ciomed Central 